\title{
To License or Not to License Revisited: An Examination of State Statutes Regarding Private Investigators and Digital Examiners
}

Thomas Lonardo

Roger Williams University

Doug White

Roger Williams University

Alan Rea

Western Michigan University

Follow this and additional works at: https://commons.erau.edu/jdfsl

Part of the Computer Engineering Commons, Computer Law Commons, Electrical and Computer Engineering Commons, Forensic Science and Technology Commons, and the Information Security Commons

\section{Recommended Citation}

Lonardo, Thomas; White, Doug; and Rea, Alan (2009) "To License or Not to License Revisited: An Examination of State Statutes Regarding Private Investigators and Digital Examiners," Journal of Digital Forensics, Security and Law. Vol. 4 : No. 3 , Article 3.

DOI: https://doi.org/10.15394/jdfsl.2009.1062

Available at: https://commons.erau.edu/jdfsl/vol4/iss3/3

This Article is brought to you for free and open access by

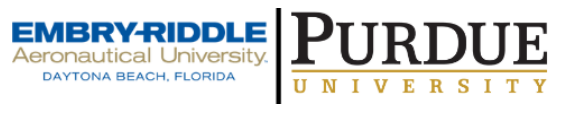
the Journals at Scholarly Commons. It has been accepted for inclusion in Journal of Digital Forensics, Security and Law by an authorized administrator of Scholarly Commons. For more information, please contact commons@erau.edu.

(c)ADFSL 


\title{
To License or Not to License Revisited: An Examination of State Statutes Regarding Private Investigators and Digital Examiners ${ }^{1}$
}

\author{
Thomas Lonardo \\ Gabelli College of Business \\ Roger Williams University \\ Bristol, RI \\ E-mail: tlonardo@rwu.edu \\ Doug White \\ FANS Center, School of Justice Studies \\ Roger Williams University \\ Bristol, RI \\ E-mail: dwhite@rwu.edu \\ Alan Rea * \\ Haworth College of Business \\ Western Michigan University \\ Kalamazoo, MI \\ E-mail alan.rea@wmich.edu \\ * Corresponding Author
}

\begin{abstract}
In this update to the previous year's study, the authors examine statutes that regulate, license, and enforce investigative functions in each US state. After identification and review of Private Investigator licensing requirements, the authors find that very few state statutes explicitly differentiate between Private Investigators and Digital Examiners. After contacting all state agencies the authors present a distinct grouping organizing state approaches to professional Digital Examiner licensing. The authors conclude that states must differentiate between Private Investigator and Digital Examiner licensing requirements and oversight.
\end{abstract}

Keywords: Digital Examiner, Computer Forensics, State Statutes, Private Investigator, Licensing Requirements

\footnotetext{
${ }^{1}$ This paper was funded by the International Association of Forensic Computer Examiners [ISFCE] and the Forensics, Advanced Networking, and Security Laboratory [FANS] at Roger Williams University.
} 


\section{INTRODUCTION}

\subsection{Historical Background}

In the United States (US), state statutes set the guidelines for identification, oversight, and licensing of various investigative functions. Many years ago some states passed legislation to manage commercial police and security specialists who undertook roles similar to officers of the court, but neither no longer, nor ever had, held badges. In most statutes these individuals are identified as Private Detectives or Private Investigators (PI), or security officers.

However, these state statutes were defined in a period when not all areas of highly technical investigation, such as Digital Examiners and Computer Forensics existed. Hence, we see confusion among state statutes and the role of these new investigative professionals. For example, many statutes commonly define all investigators as "someone who attempts to prove the truth or falsity of a statement." Unfortunately, this language is so broad that it provides the opportunity for the inclusion of virtually any investigative profession, including Digital Examiners (DE), who routinely examines systems and media to provide investigative evidence. This situation is problematic for all involved. Some states, such as Texas, have gone so far as to interpret investigation to include computer technicians and computer repair personnel (Kramer, 2009). This situation may extend itself to prevent individuals from working as they may not be able to obtain the license given the requirements of that state.

Many organizations are addressing this disjuncture between statutes and new forms of investigation. The American Bar Association issued an opinion in which they specifically urge states to realize that Digital Forensics, and by extension Digital Examiners, is a separate field. Moreover, they argue that DEs and other similar technical investigative professions, such as penetration testers, should not be required to obtain a PI license (ABA, 2009). In addition, state legislatures are now providing additional attention to this issue and due to the controversy surrounding licensing, have subsequently backed away from the position that PIs and digital forensics specialists should hold the same license, such as what occurred in North Carolina (74C-3(b)). Private protective service boards are now considering and reconsidering this issue as it relates to their states.

\subsection{Addressing the Situation}

In the original Lonardo, White, and Rea (2008) paper, the authors examined how each state, as well as Washington DC, interpreted and implemented Digital Examiner licensing. The authors found that the licensing requirements can create a conflation between DE activities and PI licensing requirements that may be detrimental to both if not correctly interpreted and implemented. In the requirements we routinely discovered interpretations of language permitting any sort of security task (e.g., Penetration Testing) to be part of the PI realm. As has been mentioned earlier, some states have gone beyond this standard to begin 
including other areas as well.

Moreover, there are diverse requirements. In some states there are no licensing requirements for Private Investigators; while in others, the profession is governed by statute and or regulatory bodies charged with the oversight and licensing. In some statutes, requirements are implicitly defined; in others the role of DE and PI is either conflated or distinguished. And in other statutes there is no guidance whatsoever.

It must be granted that Digital Examiner is a relatively new profession, but we have found that many states determine how the profession is regulated. Unfortunately, many states default to their PI licensing boards to do so. This is a matter of procedure since it allows them to combine all professional investigative licensing requirements. We see many repercussions to this decision resulting, such as the lawsuit filed in Texas by computer repair technicians who claim that this prevents them from being able to work since they cannot obtain the license based on the diverging requirements of the two professions (Rife, 2007).

In this paper, we update our original (2008) which provided the first set of responses from the state boards. We first analyze and interpret existing regulations, then discuss results of our second round of requests from state agencies for statute interpretations. We caution that we do not offer legal advice to practitioners; however, we do offer a starting point from which practitioners can make informed decisions about licensing in their state and take action accordingly. Moreover, we must stress that state legalization and statutes are continually changing because of new legal interpretations and other changes in agency perspectives. Subsequent research will follow as we track the evolution of state licensing statutes. Moreover, we have created a Twitter feed (pilaws) to provide interim updates during the course of the year between paper updates (White, Lonardo, and Rea, 2009). We encourage interested parties to follow and contribute.

\section{METHODOLOGY}

\subsection{Study Approach}

To retain consistency, we use our original definition of a Digital Examiner as a means of posing questions to the states:

A Digital Examiner deals with the extracting, gathering and analyzing data from a computer or computers, networks, and other digital media with subsequent preparation of reports and opinions on this media for evidentiary or other stated purposes such as data/digital security, audit, or assessment. (Lonardo, White, and Rea, 2008)

We use all of the reviewed state statutes from 2008 (Lonardo, et al., 2008) as a starting point for this research. The state statutes were first examined for any legislative updates including those states where there was no apparent licensing 
requirement or the Private Investigators as noted in Lonardo, et al. Additionally, the statutes were then scrutinized to determine whether the PI licensing statutes were contained in the typical "business regulation" statutory titles as found in the vast majority of states. Unless the statute clearly exempted the DE from a licensing requirement or there was no apparent PI licensing requirement at all, the appropriate regulatory body was contacted by email, postal mail, or a follow up by phone if the mail-based methods were not successful in obtaining a response. Those groups that had indicated a response to the 2008 paper were asked if there was a change in the position from the preceding year and those who had not responded previously were sent the full inquiry letter found in Figure 1.

Dear

I am researching the requirements of various Private

Investigator/Detective licensing requirements relating to

Digital/Computer Forensic Examiners. I reviewed the statute; however, I did not see any exclusion in the statute relating to whether a Private Investigator/Detective license is required for Digital/Computer Forensic Examiners. The role and activities of a Digital/Computer Forensic Examiner may include:

- $\quad$ Acquiring data from a computer

- Examining that data and opine on content

- Processing that data to obtain information to answer questions

- Processing that data to prepare it as evidence

In short, the activities of a Digital/Computer Forensic Examiner deals with the extracting, gathering and analyzing data from a computer or computers and preparing reports on the same. For example, if a government agency or private concern hires a digital examiner to determine if the information on a computer was used for fraudulent or inappropriate purposes, the examiner will extract the information from a computer or computers and make an assessment to that end.

I would greatly appreciate it if you could let me know

1) What the position of the State of is relating to the question as to whether a Private Investigator/Detective license is required for the aforementioned activities of a Digital/Computer Forensic Examiner

2) If a rule or regulation exists covering this area

3) If this issue has been settled by a hearing of the Licensing Board could you please send me the official decision/position of the Board.

Figure 1 
All requests were sent via email when this was possible which allowed for ease of contact, simplification of analysis, and record of the response provided. Inquiries were conducted from April 2009 to September 2009 because many legislative sessions conclude in April or May and resume in September or October. Our survey time frame situates itself as best suited the analysis with regards to likely changes in the state statutes.

It is worth noting that each state manages these regulating bodies in differing ways and thus we use the term "regulatory body" as a means to describe the various entities (e.g. Protective Services Board, Department of Public Safety, etc.).

As per the original research (Lonardo, et al., 2008), when we advocated an opinion, we based it solely on the language contained in the state's code. For example, if a state used language, such as "to prove the truth of falsity of a statement," or "performing investigations for the court," or similar language, we classified our opinion as "likely required." Other states used strong exclusionary language without being specific, such as "exceptions include engineers and scientists." When we encountered this language that implies scientific investigation, we classified our opinion as "likely not required."

As in the past, all of the opinions are subjective and based on our reading of present state codes and the continuation of those opinions from the 2008 paper. As our study demonstrates, state boards have varying opinions; language is subject to varying interpretations and in cases where we did not receive responses from state officials, our opinion should be taken in the same context.

\subsection{Examination of Language Used}

Lonardo, et al. (2008) provides a review of the language which is typical of the various states. Still we pose some brief samples here to illustrate the challenges faced when determining particular state statute application to the licensing question. Figure 2 provides an illustration from Arizona:

A similar set of language is found in Texas as is seen in Figure 3. 
The Arizona Statute Title $\mathbf{3 2 ~} \S \mathbf{2 4 1 0}$ defines a Private Investigator.

"Private investigator" means a person other than an insurance adjuster or an onduty peace officer as defined in section 1-215 who, for any consideration, engages in business or accepts employment to:

(a) Furnish, agree to make or make any investigation for the purpose of obtaining information with reference to:

(i) Crime or wrongs done or threatened against the United States or any state or territory of the United States.

(ii) The identity, habits, conduct, movements, whereabouts, affiliations, associations, transactions, reputation or character of any person or group of persons.

(iii) The credibility of witnesses or other persons.

(iv) The whereabouts of missing persons, owners of abandoned property or escheated property or heirs to estates.

(v) The location or recovery of lost or stolen property.

(vi) The causes and origin of, or responsibility for, a fire, libel, slander, a loss, an accident, damage or an injury to real or personal property.

(b) Secure evidence to be used before investigating committees or boards of award or arbitration or in the trial of civil or criminal cases and the preparation therefor.

(c) Investigate threats of violence and provide the service of protection of individuals from serious bodily harm or death.

Figure 2: Arizona Statute Title 32 § 2410

\section{Sec. 1702.104. INVESTIGATIONS COMPANY.}

(a) A person acts as an investigations company for the purposes of this chapter if the person:

(1) engages in the business of obtaining or furnishing, or accepts employment to obtain or furnish, information related to:

(A) crime or wrongs done or threatened against a state or the United States;

(B) the identity, habits, business, occupation, knowledge, efficiency, loyalty, movement, location, affiliations, associations, transactions, acts, reputation, or character of a person;

(C) the location, disposition, or recovery of lost or stolen property; or

(D) the cause or responsibility for a fire, libel, loss, accident, damage, or injury

to a person or to property;

Figure 3: Texas Occupations Code Title $10 \S 1702.104$ (a) excerpt 
As noted earlier in our discussion, Texas has extended this code to include specifics regarding Computer Technology as seen in Figure 4. This has caused some contention from computer-based business owners and technicians.

(b) For purposes of Subsection (a)(1), obtaining or furnishing information includes information obtained or furnished through the review and analysis of, and the investigation into the content of, computer-based data not available to the public.

Figure 4: Texas Occupations Code Title 10 § 1702.104(b)

The Connecticut statute under Chapter 534 Sec. 29-152u (4) defines a PI in almost the same terms as the Arizona statute (Figure 5).

"Private detective" means any person engaged in the business of, or advertising as engaged in the business of (A) investigating crimes or civil wrongs, (B) investigating the location, disposition or recovery of property, (C) investigating the cause of accidents, fire damage or injuries to persons or to property, except persons performing bona fide engineering services, (D) providing the personal protection of individuals, (E) conducting surveillance activity, (F) conducting background investigations, or (G) securing evidence to be used before a court, board, officer or investigation committee; ...

Figure 5: Connecticut statute under Chapter 534 Sec. 29-152u (4)

However, under Connecticut's statutory language, the regulator we contacted noted that a PI license--and by extension a Digital Examiner--is not required. We have found that this open-ended interpretation has resulted in many states interpreting the Digital Examiner role and profession disparately and inconsistently.

Vague language and diverse interpretation is still the norm, such as with the language used to determine licensing requirements in Nebraska's statute (Neb. Rev. Stat. § 71-3201) (Figure 6).

(6) Private detective shall mean any individual who as a sole proprietor engages in the private detective business without the assistance of any employee;

(8) Private detective business shall mean and include any private business engaged in by any person defined in subdivision (4) of this section who advertises or holds himself or herself out to the public, in any manner, as being engaged in the secret service or private policing business;

Figure 6: Nebraska Rev. Stat. § 71-3201 
Under Nebraska's statute a private detective is one who is "engaged in the secret service or private policing business." However, neither the functionality of Arizona's nor Connecticut's statutes is incorporated into the language of the Nebraska statute. Thus, in Nebraska's opinion, a license is not required.

However, we did find that Nebraska's Chapter $1 \S \mathbf{0 0 2}$ of the "Rules \& Regulations for Private Detective, Plain Clothes Investigators and Private Detective Agencies" does explain the profession's functionality in greater detail even though it is not as specific as others we examined (Figure 7).

002. Secret service or private policing business shall mean and include: general investigative work; non-uniformed security services; surveillance services; location of missing persons; and background checks.

Figure 7: Nebraska Chapter $1 \S 002$

It is apparent to us that these statues were developed with a very general idea of the role played by security officers and have been interpreted in diverging manners by different states. To illustrate changing interpretation approaches, we need to look at North Carolina, which has similar language (Figure 8) initially leaned towards requirement of PI licenses for anyone conducting digital forensics.

(8) Private detective or private investigator. Any person who engages in the profession of or accepts employment to furnish, agrees to make, or makes inquiries or investigations concerning any of the following on a contractual basis:

a. Crimes or wrongs done or threatened against the United States or any state or territory of the United States.

b. The identity, habits, conduct, business, occupation, honesty, integrity, credibility, knowledge, trustworthiness, efficiency, loyalty, activity, movement, whereabouts, affiliations, associations, transactions, acts, reputation, or character of any person.

c. The location, disposition, or recovery of lost or stolen property.

d. The cause or responsibility for fires, libels, losses, accidents, damages, or injuries to persons or to properties.

e. Securing evidence to be used before any court, board, officer, or investigative committee.

Figure 8: North Carolina General Statutes § 74C-3 
However after hearings on the matter, the Protective Services Board (PSB) elected to withdraw its recommendation that Digital Forensics be controlled by the PSB in North Carolina. Subsequently, the state codified this recommendation into an exclusion in August of 2009 (NC 74C-3(b)). We strongly commend North Carolina's PSB for this decision and encourage other states to follow its lead to define and codify their interpretations.

Ultimately, despite similar language, states have a variety of interpretations. Although improved from the previous year's study, we find there is still too much diversity in regards to expectations, definitions, requirements, and assumptions. This underscores the need for diligence on the part of practitioners in monitoring this issue.

\subsection{Exemptions in the Language}

We must point out that many of the state statutes did not need interpretation because they listed exemptions to the PI licensing requirement. Most, if not all, of these exemptions would exclude a Digital Examiner from PI licensing requirements, but perhaps not other professional licensing requirements (e.g., State Bar Exam) or certification (e.g., CPA). The exemptions typically included:

- Persons under the regular employment of an employer where there is a bona fide employer-employee relationship;

- An officer or employee of the United States, the state where the public employee is employed, or a political subdivision of the state;

- The business of obtaining and furnishing information as to the financial standing, rating, and credit responsibility of persons or as to the personal habits and financial responsibility of applicants for insurance, indemnity bonds, or commercial credit;

- A charitable philanthropic society or association;

- An attorney admitted to practice in the state in performing his or her duties as an attorney at law;

- A collection agency or finance company licensed to do business under the laws of this state or any employee of a collection agency or finance company while performing within the scope of their duties;

- Claims adjusters of insurance companies;

- A professional engineer acting within the scope of his or her licensed professional practice who does not perform investigative services;

- A certified public accountant acting within the scope of his or her licensed professional practice who does not perform investigative services;

- Bail agents.

In a similar fashion to the requirements, the exemptions follow no particular pattern but do in some cases exclude practitioners either directly or indirectly. 


\section{DISCUSSION OF FINDINGS}

\subsection{Initial Review}

As noted above, we began our review by reexamining the state statutes from the previous year. We list all the statues in Table 1.

Table 1: State Statutes

\begin{tabular}{|c|c|}
\hline State & Statute \\
\hline Alabama & No Requirement \\
\hline Alaska & No Requirement \\
\hline Arizona & Chap. $24-32-2401$ \\
\hline Arkansas & $17-40$ \\
\hline California & 7520 State Law \\
\hline Colorado & None found \\
\hline Connecticut & Chap. 534 Sec 29 \\
\hline Delaware & $24-1301$ \\
\hline District of Columbia & Division VIII Title 47 \\
\hline Florida & Title 32 Chap. 493 \\
\hline Georgia & Title 43 - Chap. 38 \\
\hline Hawaii & HRS Chap. 463 \\
\hline Idaho & No Requirement \\
\hline Illinois & 225 ILCS 447 Art 5-10.1.2 \\
\hline Indiana & IC $25-30$ \\
\hline Iowa & IC Chap. 80A \\
\hline Kansas & Chap. 75 - 7b \\
\hline Kentucky & KRS 329A \\
\hline Louisiana & LA RS:37 3500 \\
\hline Maine & Title 32 - Chap. 89 \\
\hline Maryland & Title 13-101 \\
\hline Massachusetts & Title XX 147 s22 \\
\hline Michigan & Chap. 338.822 \\
\hline Minnesota & 326.338 \\
\hline Mississippi & NA \\
\hline Missouri & NA \\
\hline Montana & $37-60-105$ \\
\hline Nebraska & $72-3201$ \\
\hline Nevada & 648.012 \\
\hline New Hampshire & $106-\mathrm{F}$ \\
\hline New Jersey & $45: 19-9$ \\
\hline New Mexico & 61 Article 27B \\
\hline New York & Article 7 Sec 71 \\
\hline
\end{tabular}




\begin{tabular}{|ll|}
\hline \multicolumn{1}{|c|}{ State } & Statute \\
\hline North Carolina & 74 C-3(b) \\
\hline North Dakota & $43-30$ \\
\hline Ohio & 4749.01 \\
\hline Oklahoma & Title 59 - 42a-1750 \\
\hline Oregon & 703.401, 405, 407, 411 \\
\hline Pennsylvania & Unknown \\
\hline Rhode Island & Chap. 5-5 \\
\hline South Carolina & Title 40 Chap. 18 \\
\hline South Dakota & No Requirement \\
\hline Tennessee & Title 62 Chap. 26 223 \\
\hline Texas & 1702.104 \\
\hline Utah & 53-9-102 \\
\hline Vermont & Title 26 Chap. 59 \\
\hline Virginia & $9-1-138$ \\
\hline Washington & 18.165 .10 \\
\hline West Virginia & $30-18$ \\
\hline Wisconsin & 440.26 \\
\hline Wyoming & No Requirement \\
\hline
\end{tabular}

\subsection{Summary of Responses}

After we reviewed the statutes, we began a new round of inquiries to the states as per our methodology. The responses ranged from "No License Required," "License Required" and a new response "License required with limiting circumstances."

We found this new response intriguing because it is a distinct change from the previous year's responses. Because of this shift in approach, we created a new table category to note it (Table 8). For example, the District of Columbia mandates a physical presence in DC in order to require a license. However, if the computer or data is originally obtained in DC, but the examination of the evidence is conducted in a state not requiring a license, a DC license is then not required.

In Nevada, the board opined that "The Board did not license data recovery, but what was done with that information would require an investigators license." This would then exclude imaging but would cover examination. Wisconsin and California have taken a similar position to Nevada. We expect states to make more distinctions such as these are they begin to understand the differences between PI and DE.

One major change between 2008 and this current study is in the response rate. In 2008, we received no response from 16 states, but in the 2009 study only 3 (three) 
states failed to generate a response of some kind. This provided a marked increase over the 2008 study in terms of response. We are definitely pleased with this result and hope to have a complete return rate in next year's study.

Table 2 provides linkages to the state statutes with the Title and Part of the statute that directly refers to this study.

Table 2: State Statutes and Links

\begin{tabular}{|c|c|c|c|}
\hline State & Belief & Statute & Website \\
\hline Alabama & $\begin{array}{l}\text { No PI } \\
\text { Licensing } \\
\text { Requirement }\end{array}$ & & \\
\hline Alaska & $\begin{array}{l}\text { No PI } \\
\text { Licensing } \\
\text { Requirement }\end{array}$ & & \\
\hline Arizona & $\begin{array}{l}\text { Not specific } \\
\text { but statements }\end{array}$ & $\begin{array}{l}\text { Chap. } 24 \text { - } \\
32 \text { - } 2401\end{array}$ & $\begin{array}{l}\text { http://www.azleg.state.az.us/FormatD } \\
\text { ocument.asp?inDoc=/ars/32/02401.ht } \\
\text { m\&Title=32\&DocType=ARS }\end{array}$ \\
\hline Arkansas & $\begin{array}{l}\text { Not Specific } \\
\text { but statements }\end{array}$ & $17-40$ & $\begin{array}{l}\text { http://www.arkleg.state.ar.us/bureau/P } \\
\text { ublications/Arkansas\%20Code/Title\% } \\
\text { 2017.pdf }\end{array}$ \\
\hline California & $\begin{array}{l}\text { Not Specific } \\
\text { but statements }\end{array}$ & $\begin{array}{l}7520 \text { State } \\
\text { Law }\end{array}$ & $\begin{array}{l}\text { http://www.leginfo.ca.gov/cgi- } \\
\text { bin/displaycode?section=bpc\&group= } \\
\text { 07001-08000\&file=7520-7539 }\end{array}$ \\
\hline Colorado & $\begin{array}{l}\text { No PI } \\
\text { Licensing } \\
\text { Requirement }\end{array}$ & $\begin{array}{l}\text { None } \\
\text { found }\end{array}$ & \\
\hline Connecticut & $\begin{array}{l}\text { Not Specific } \\
\text { but statements }\end{array}$ & $\begin{array}{l}\text { Chap. } 534 \\
\text { Sec. } 29\end{array}$ & $\begin{array}{l}\text { http://www.cga.ct.gov/2005/pub/Chap } \\
\text { 534.htm\#Sec29-153.htm }\end{array}$ \\
\hline Delaware & $\begin{array}{l}\text { PI but } \\
\text { excludes CCE }\end{array}$ & $24-1301$ & $\begin{array}{l}\text { http://delcode.delaware.gov/title24/c0 } \\
\text { 13/index.shtml }\end{array}$ \\
\hline $\begin{array}{l}\text { District of } \\
\text { Columbia }\end{array}$ & $\begin{array}{l}\text { Seems to } \\
\text { require but } \\
\text { unknown }\end{array}$ & $\begin{array}{l}\text { Division } \\
\text { VIII Title } \\
47\end{array}$ & \\
\hline Florida & $\begin{array}{l}\text { Not Specific } \\
\text { but statements }\end{array}$ & $\begin{array}{l}\text { Title } 32 \\
\text { Chap. } 493\end{array}$ & $\begin{array}{l}\text { http://www.flsenate.gov/Statutes/inde } \\
\text { X.cfm?App_mode=Display_Statute\& } \\
\text { URL=Ch0493/titl0493.htm }\end{array}$ \\
\hline Georgia & $\begin{array}{l}\text { Not Specific } \\
\text { but statements }\end{array}$ & $\begin{array}{l}\text { Title } 43- \\
\text { Chap. } 38\end{array}$ & $\begin{array}{l}\text { http://www.lexis- } \\
\text { nexis.com/hottopics/gacode/Default.as } \\
\text { p }\end{array}$ \\
\hline Hawaii & $\begin{array}{l}\text { May imply as } \\
\text { it states all } \\
\text { investigation }\end{array}$ & $\begin{array}{l}\text { HRS Chap. } \\
463\end{array}$ & $\begin{array}{l}\text { http://hawaii.gov/dcca/pvl/hrs/hrs_pvl } \\
\text { 463.pdf/view }\end{array}$ \\
\hline
\end{tabular}




\begin{tabular}{|c|c|c|c|}
\hline State & Belief & Statute & Website \\
\hline Idaho & $\begin{array}{l}\text { No PI } \\
\text { Licensing } \\
\text { Requirement }\end{array}$ & & \\
\hline Illinois & $\begin{array}{l}\text { Includes } \\
\text { "electronics" } \\
\text { in the } \\
\text { definition of } \\
\text { investigation. }\end{array}$ & $\begin{array}{l}225 \text { ILCS } \\
447 \text { Art 5- } \\
10.1 .2\end{array}$ & $\begin{array}{l}\text { http://ilga.gov/legislation/ilcs/ilcs5.asp } \\
\text { ?ActID=2474\&ChapAct=225\%A0ILC } \\
\text { S\%A0447\%2F\&ChapterID=24\&Chap } \\
\text { terName=PROFESSIONS+AND+OC } \\
\text { CUPATIONS\&ActName=Private+De } \\
\text { tective\%2C+Private+Alarm\%2C+Priv } \\
\text { ate+Security\%2C+and+Locksmith+A } \\
\text { ct+of+2004\%2E }\end{array}$ \\
\hline Indiana & $\begin{array}{l}\text { Not Specific } \\
\text { but statements }\end{array}$ & IC $25-30$ & $\begin{array}{l}\text { http://www.in.gov/legislative/ic/code/t } \\
\text { itle25/ar30/ch1.html }\end{array}$ \\
\hline Iowa & $\begin{array}{l}\text { Not Specific } \\
\text { but statements }\end{array}$ & $\begin{array}{l}\text { IC Chap. } \\
80 \mathrm{~A}\end{array}$ & $\begin{array}{l}\text { http://www.dps.state.ia.us/asd/pi/pi80a } \\
\text { 03code.pdf }\end{array}$ \\
\hline Kansas & $\begin{array}{l}\text { Not Specific } \\
\text { but statements }\end{array}$ & $\begin{array}{l}\text { Chap. } 75 \text { - } \\
\text { 7b }\end{array}$ & $\begin{array}{l}\text { http://www.kslegislature.org/legsrv- } \\
\text { statutes/index.do }\end{array}$ \\
\hline Kentucky & $\begin{array}{l}\text { Not Specific } \\
\text { but statements }\end{array}$ & KRS 329A & $\begin{array}{l}\text { http://www.lrc.state.ky.us/KRS/329A0 } \\
\text { 0/CHAPTER.HTM }\end{array}$ \\
\hline Louisiana & $\begin{array}{l}\text { Excludes } \\
\text { technical } \\
\text { experts } \\
\end{array}$ & $\begin{array}{l}\text { LA RS:37 } \\
3500\end{array}$ & $\begin{array}{l}\text { http://www.lsbpie.com/pilaw_4_02.pd } \\
\underline{\mathrm{f}}\end{array}$ \\
\hline Maine & $\begin{array}{l}\text { Not Specific } \\
\text { but statements }\end{array}$ & $\begin{array}{l}\text { Title } 32- \\
\text { Chap. } 89\end{array}$ & $\begin{array}{l}\text { http://janus.state.me.us/legis/statutes/3 } \\
\text { 2/title32ch89.pdf }\end{array}$ \\
\hline Maryland & $\begin{array}{l}\text { Not Specific } \\
\text { but statements }\end{array}$ & $\begin{array}{l}\text { Title 13- } \\
101\end{array}$ & $\begin{array}{l}\text { http://michie.lexisnexis.com/maryland } \\
\text { lpext.dll/mdcode/1564/227a?fn=docu } \\
\text { ment-frame.htm\&f=templates\&2.0\# }\end{array}$ \\
\hline Massachusetts & $\begin{array}{l}\text { Not Specific } \\
\text { but statements }\end{array}$ & $\begin{array}{l}\text { Title XX } \\
147 \text { s22 }\end{array}$ & $\begin{array}{l}\text { http://www.mass.gov/legis/laws/mgl/g } \\
\text { l-147-toc.htm }\end{array}$ \\
\hline Michigan & $\begin{array}{l}\text { Not Specific } \\
\text { but statements }\end{array}$ & $\begin{array}{l}\text { Chap. } \\
338.822\end{array}$ & $\begin{array}{l}\text { http://www.legislature.mi.gov/(S(543g } \\
\text { jn45g1xwihrunhpsds45))/mileg.aspx? } \\
\text { page=getObject\&objectName=mcl- } \\
\text { Act-285-of-1965 }\end{array}$ \\
\hline Minnesota & $\begin{array}{l}\text { Not Specific } \\
\text { but statements }\end{array}$ & 326.338 & $\begin{array}{l}\text { http://www.dps.state.mn.us/pdb/Resou } \\
\text { rces/PDPA_Minnesota_Statutes.pdf }\end{array}$ \\
\hline Mississippi & Not Specific bu & statements & \\
\hline Missouri & $\begin{array}{l}\text { Not Specific } \\
\text { but statements }\end{array}$ & $\begin{array}{l}\text { XXII } \\
324.1100\end{array}$ & $\begin{array}{l}\text { http://www.moga.mo.gov/statutes/cha } \\
\text { pters/chap324.htm }\end{array}$ \\
\hline Montana & $\begin{array}{l}\text { Not Specific } \\
\text { but statements }\end{array}$ & $37-60$ & $\begin{array}{l}\text { http://data.opi.state.mt.us/bills/mca_to } \\
\text { c/37 60 1.htm }\end{array}$ \\
\hline Nebraska & $\begin{array}{l}\text { Should not } \\
\text { apply unless } \\
\text { you advertise } \\
\text { as private } \\
\text { detective }\end{array}$ & $72-3201$ & $\begin{array}{l}\text { http://www.sos.state.ne.us/rules-and- } \\
\text { regs/regsearch/Rules/Secretary_of_Sta } \\
\text { te/Title-435.pdf }\end{array}$ \\
\hline
\end{tabular}




\begin{tabular}{|c|c|c|c|}
\hline State & Belief & Statute & Website \\
\hline Nevada & $\begin{array}{l}\text { Not Specific } \\
\text { but statements }\end{array}$ & 648.012 & $\begin{array}{l}\text { http://www.leg.state.nv.us/NRS/NRS- } \\
\text { 648.html\#NRS648Sec006 }\end{array}$ \\
\hline $\begin{array}{l}\text { New } \\
\text { Hampshire }\end{array}$ & $\begin{array}{l}\text { Not Specific } \\
\text { but crime } \\
\text { statement }\end{array}$ & $106-\mathrm{F}$ & $\begin{array}{l}\text { http://www.gencourt.state.nh.us/rsa/ht } \\
\underline{\text { ml/vii/106-f/106-f-mrg.htm }}\end{array}$ \\
\hline New Jersey & $\begin{array}{l}\text { Not Specific } \\
\text { but statements }\end{array}$ & $45: 19-9$ & $\begin{array}{l}\text { http://www.state.nj.us/njsp/about/pdf/ } \\
\text { 060106 amendedstat.pdf }\end{array}$ \\
\hline New Mexico & $\begin{array}{l}\text { Not Specific } \\
\text { but statements }\end{array}$ & $\begin{array}{l}\text { 61 Article } \\
27 \mathrm{~B}\end{array}$ & $\begin{array}{l}\text { http://www.conwaygreene.com/nmsu/l } \\
\text { pext.dll/nmsa1978/9b0/1d78b/1ef8f/1f } \\
\text { 105?f=templates\&fn=document- } \\
\text { frame.htm\&2.0 }\end{array}$ \\
\hline New York & $\begin{array}{l}\text { Not Specific } \\
\text { but statements }\end{array}$ & $\begin{array}{l}\text { Article } 7 \\
\text { Sec } 71\end{array}$ & $\begin{array}{l}\text { http://www.dos.state.ny.us/lcns/lawbo } \\
\text { oks/pibeawgpa.html }\end{array}$ \\
\hline $\begin{array}{l}\text { North } \\
\text { Carolina }\end{array}$ & $\begin{array}{l}\text { Excluded } \\
\text { Indirectly }\end{array}$ & $74 \mathrm{C}-3$ & $\begin{array}{l}\text { http://www.ncleg.net/EnactedLegislati } \\
\text { on/Statutes/HTML/ByChapter/Chapte } \\
\text { r 74C.html }\end{array}$ \\
\hline North Dakota & Excluded & $43-30$ & $\begin{array}{l}\text { http://www.legis.nd.gov/cencode/t43c } \\
\text { 30.pdf }\end{array}$ \\
\hline Ohio & $\begin{array}{l}\text { Not Specific } \\
\text { but statements }\end{array}$ & 4749.01 & http://codes.ohio.gov/orc/4749 \\
\hline Oklahoma & $\begin{array}{l}\text { Not Specific } \\
\text { but statements }\end{array}$ & $\begin{array}{l}\text { Title } 59 \text { - } \\
42 a-1750\end{array}$ & $\begin{array}{l}\text { http://www.oscn.net/applications/oscn } \\
\text { /DeliverDocument.asp?CiteID=96644 }\end{array}$ \\
\hline Oregon & $\begin{array}{l}\text { Not Specific } \\
\text { but statements }\end{array}$ & 703.4 & http://www.leg.state.or.us/ors/703.htm \\
\hline Pennsylvania & \multicolumn{3}{|c|}{ License is required in some counties. } \\
\hline Rhode Island & $\begin{array}{l}\text { Not Specific } \\
\text { but statements }\end{array}$ & Chap. 5-5 & $\begin{array}{l}\text { http://www.rilin.state.ri.us/Statutes/Tit } \\
\text { le5/5-5/INDEX.HTM }\end{array}$ \\
\hline $\begin{array}{l}\text { South } \\
\text { Carolina }\end{array}$ & $\begin{array}{l}\text { Not Specific } \\
\text { but statements }\end{array}$ & $\begin{array}{l}\text { Title } 40 \\
\text { Chap. } 18\end{array}$ & $\begin{array}{l}\text { http://www.scstatehouse.net/code/t40c } \\
\text { 018.htm }\end{array}$ \\
\hline South Dakota & $\begin{array}{l}\text { No PI } \\
\text { Licensing } \\
\text { Requirement }\end{array}$ & & \\
\hline Tennessee & $\begin{array}{l}\text { Not Specific } \\
\text { but statements }\end{array}$ & $\begin{array}{l}\text { Title } 62 \\
\text { Chap. } 26 \\
223\end{array}$ & $\begin{array}{l}\frac{\text { http://michie. lexisnexis.com/tenne }}{\text { ssee/lpext.dll/tncode/24296/24fbc/ }} \\
\underline{24 \mathrm{fc} 3 / 25044 ? \mathrm{f}=\text { templates } \& \mathrm{fn}=\mathrm{doc}} \\
\underline{\text { ument-frame.htm\&2.0\#]D } 62-26-}\end{array}$ \\
\hline Texas & $\begin{array}{l}\text { Specifically } \\
\text { includes CF }\end{array}$ & 1702.104 & $\begin{array}{l}\text { http://www.statutes.legis.state.tx.us/D } \\
\text { ocs/OC/htm/OC.1702.htm }\end{array}$ \\
\hline Utah & $\begin{array}{l}\text { Not Specific } \\
\text { but statements }\end{array}$ & $53-9-102$ & $\begin{array}{l}\text { http://le.utah.gov/UtahCode/getCodeS } \\
\text { ection?code=53-9-102 }\end{array}$ \\
\hline Vermont & $\begin{array}{l}\text { Not Specific } \\
\text { but statements }\end{array}$ & $\begin{array}{l}\text { Title } 26 \\
\text { Chap. } 59 \\
\end{array}$ & $\begin{array}{l}\text { http://www.leg.state.vt.us/statutes/full } \\
\text { chapter.cfm?Title=26\&Chapter=059 }\end{array}$ \\
\hline
\end{tabular}




\begin{tabular}{|c|c|c|c|}
\hline State & Belief & Statute & Website \\
\hline Virginia & $\begin{array}{l}\text { Specifically } \\
\text { excludes } \\
\text { forensics } \\
\text { examiners }\end{array}$ & $9-1-138$ & $\begin{array}{l}\underline{\text { http://leg1.state.va.us/cgi- }} \\
\underline{\text { bin/legp504.exe?000+cod+9.1-138 }}\end{array}$ \\
\hline Washington & $\begin{array}{l}\text { Specifically } \\
\text { excludes } \\
\text { forensics } \\
\text { examiners }\end{array}$ & 18.165 .10 & $\begin{array}{l}\text { http://apps.leg.wa.gov/RCW/default.as } \\
\text { px?cite=18.165.010 }\end{array}$ \\
\hline West Virginia & $\begin{array}{l}\text { Not Specific } \\
\text { but strong } \\
\text { language }\end{array}$ & $30-18$ & $\begin{array}{l}\text { http://www.legis.state.wv.us/WVCOD } \\
\underline{\text { E/Code.cfm?chap=30\&art=18 }}\end{array}$ \\
\hline Wisconsin & $\begin{array}{l}\text { No Specific } \\
\text { language at all } \\
\text { but focused on } \\
\text { advertising as } \\
\text { private } \\
\text { detective }\end{array}$ & 440.26 & $\begin{array}{l}\text { http://www.legis.state.wi.us/statutes/St } \\
\underline{\text { at0440.pdf }}\end{array}$ \\
\hline Wyoming & $\begin{array}{l}\text { No PI } \\
\text { Licensing Req. }\end{array}$ & & \\
\hline
\end{tabular}

During the time frame of April 2009 to September 2009, we solicited responses from the various states using our established methods. The data is presented in tables based upon several factors. In some cases, the state has a statute which requires the license or does not require the license. In other cases, the opinion of the governing body was used based on their response to our inquiry. In all cases, we have attempted to provide an informational resource for practitioners but again must caution that both opinion and statute are dynamic and can change rapidly. Thus, as ever, the practitioner should use caution and contact a licensed attorney or the state licensing board before conducting forensics examinations in any given locale.

The data is presented as follows:

- States that require a PI license and specifically address DEs by statute. (Table 3)

- States that require a PI license, but do not specifically address DEs. There is an opinion issued that includes DEs. (Table 4)

- States that require a PI license, but do not specifically include DEs. There is a present opinion issued that excludes DEs. (Table 5)

- States that require a PI license and specifically exclude DEs by statute. (Table 6)

- States that do not require a PI license by statute. (Table 7)

- States that require a PI license but have limited exclusions for DE (Table 8) 
- States that did not respond to our inquiry (Table 9)

- States that issues a response of no opinion (Table 10)

Table 3: States that require a PI License and specifically include DEs by statute

\begin{tabular}{|l|l|l|}
\hline State & Requires PI for DE & Statute \\
\hline IL & Indirectly but Yes & $\begin{array}{l}\text { 225 ILCS 447, Art 5- } \\
10.1 .2\end{array}$ \\
\hline MI & Yes & Chap. 338.822 \\
\hline OR & Yes & $703.401,405,407,411$ \\
\hline TX & Yes & TC 1702.104 \\
\hline
\end{tabular}

Table 4: States that require a PI license, but do not specifically address DEs. There is an opinion issued that includes DEs.

*Indicates a state which indicated some limited exclusions (see Table 8).

\begin{tabular}{|ll|}
\hline State & Opinion \\
\hline AR & License Required \\
\hline AZ & License Required \\
\hline CA & License Required \\
\hline DC & License Required \\
\hline HI & License Required \\
\hline IA & License Required \\
\hline LA & License Required \\
\hline MD & License Required \\
\hline MO & License Required \\
\hline NH & License Required \\
\hline NV & License Required \\
\hline NY & License Required \\
\hline SC & License Required \\
\hline WV & License Required \\
\hline WI & License Required \\
\hline
\end{tabular}


Table 5: States that require a PI license, but do not specifically include DEs. There is a present opinion issued that excludes DEs.

\begin{tabular}{|l|l|}
\hline State & Opinion \\
\hline CT & No License Required \\
\hline FL & No License Required \\
\hline KS & No License Required \\
\hline OH & No License Required \\
\hline OK & No License Required \\
\hline UT & No License Required \\
\hline VT & No License Required \\
\hline
\end{tabular}

Table 6: States that require a PI license and specifically exclude DEs by statute.

\begin{tabular}{|l|l|}
\hline State & Statute \\
\hline DE & DSC 24-1301 \\
\hline MT & 37-60-105 \\
\hline NC & 74C-3(b) \\
\hline ND & NDSC 43-30 \\
\hline NE & Rev. Stat. 72-3201 \\
\hline RI & RSC Chap 5-5 \\
\hline VA & VSC 9-1-138 \\
\hline WA & WSC 18.165.10 \\
\hline
\end{tabular}

Table 7: States that do not require a PI license by statute.

\begin{tabular}{|l|l|}
\hline State & Requirement \\
\hline AL & None \\
\hline AK & None \\
\hline CO & None \\
\hline ID & None \\
\hline MS & None \\
\hline PA & May be required by county \\
\hline SD & None \\
\hline WY & None \\
\hline
\end{tabular}


Table 8: States indicating a limited exclusion but otherwise requiring a license

\begin{tabular}{|l|l|}
\hline State & Exclusion \\
\hline CA & $\begin{array}{l}\text { Via Phone Interview, written or verbal } \\
\text { inquiries would require PI but working } \\
\text { only on a computer would not. }\end{array}$ \\
\hline DC & $\begin{array}{l}\text { Work not being physically done in DC } \\
\text { would not require a license. }\end{array}$ \\
\hline LA & 37:3500.8(a)(iv) excludes technical experts \\
\hline NV & $\begin{array}{l}\text { Licensing board minutes indicate retrieval } \\
\text { is not licensed but analysis requires license }\end{array}$ \\
\hline
\end{tabular}

Only three states did not reply to email, mail, or telephone contact attempts. These three states and our opinion are listed below in Table 9.

Table 9: States with Unknown Status

\begin{tabular}{|l|l|l|}
\hline State & Status & Our Opinion \\
\hline GA & No Response & May be Required \\
\hline MA & No Response & Hearsay indicates required \\
\hline NM & No Response & May be Required \\
\hline
\end{tabular}

Of states that did respond, five (5) declined to render an opinion on DE licensing requirements (Table 10):

Table 10: States that issued a response of No Opinion

\begin{tabular}{|c|c|c|}
\hline State & Response & Our Opinion \\
\hline IN & No Opinion & Only if you advertise as a PI \\
\hline$\overline{K Y}$ & No Opinion & $\begin{array}{l}\text { Implies any sort of investigation } \\
\text { requires a license. }\end{array}$ \\
\hline$\overline{\mathbf{M N}}$ & No Opinion & May be required \\
\hline ME & No Opinion & May be required \\
\hline NJ & $\begin{array}{l}\text { Indicated it was under } \\
\text { review }\end{array}$ & Waiting for review \\
\hline $\mathbf{T N}$ & No Opinion & May be required \\
\hline
\end{tabular}

\subsection{Initial Analysis}

Our review of the 50 states and the District of Columbia indicates that four (4) states require DEs to have a license (Table 3). Fifteen (15) additional states have issued opinions that their statute would require a PI license to operate in that state (Table 4). Four (4) of those states indicated there were some limited exclusions to 
this opinion (Table 8). Seven (7) states issued opinions that DEs are excluded (Table 5). Eight (8) states exclude DEs by statute (Table 6). Eight (8) states require no licensing of PIs or DEs (Table 7). The remaining states either did not respond (Table 9) or issued a no opinion on the matter (Table 10) for a total of nine (9) states.

\section{RECOMMENDATIONS}

We would argue that it is not in the best interests of Digital Examiners, nor is it in the best interest of citizens, that DEs be licensed as Private Investigators. This is not to say that states should not license Digital Examiners, but rather should separate the two into their respective parts. Digital Examiners have a specific role in investigations that does not overlap with those duties normally performed by Private Investigators. Conversely, the implication that PI's are capable of conducting DE investigations because they are licensed is harmful to all concerned.

Upon review of the requirements in various states it is often the case that PI licensing requires thousands of hours of apprenticeship as a PI or a law enforcement background. Neither of these skill sets intersects with that of DE necessarily and thus prevents Digital Examiners from doing their job and thus denies citizens and organizations access to these individuals in those states or deprives those individuals of the right to work in those states.

These two investigative specializations rarely, if ever, converge. Thus, we recommend that states approach their regulation, licensing, and enforcement of Digital Examiners and Private Investigators as follows:

1. Adopt a clear definition of Digital Examiners.

2. Adopt a clear definition of Private Investigators.

3. Review certifications and determine which certifications are recognized by that state for the role of DEs.

4. Create a license for DE that is not governed by the PI board of the state. PI boards do not necessarily understand what is involved in DE practice. This board should be comprised of DE certified citizens holding vendor neutral certifications that include ethics policies and review, as well as regular recertification (e.g., Certified Computer Examiner type certifications [ISFCE, 2009]).

5. Barring the above, states should exclude DE from the requirement of a PI license much as they do forensic accountants, engineers, and others as per Rhode Island, Delaware, and others listed in Table 6. 


\section{CONCLUSION}

We strongly encourage state constituents and practitioners to initiate action with their legislatures to implement the five (5) steps outlined above as well as to review professional recommendations such as ABA 301 (2009). Digital Examiners would, of course, be the best coalition to advocate for these changes. However, we would advocate a series of targeted educational materials first be made to inform DEs of their particular state's regulations and licensing because only a small fraction know whether PI licenses are obtainable, desirable, or relevant to their profession (White \& Micheletti, 2008). We also encourage Computer Forensic and other technology-related organizations to advocate for state regulatory and licensing changes.

Ultimately, we would argue that it is best to exclude Digital Examiners from an established Private Investigator licensing requirement, and rely on other professional certifications, such as the Certified Computer Examiner (ISFCE, 2009) or the GCFA (SANS, 2009). This ensures that citizens, state government, and businesses have access to the most ethical and qualified individuals to conduct their forensics examinations and manage digital evidence.

\section{REFERENCES}

Addo Enterprises, Inc. (2009). PI State Licensing Requirements. Safety Basement. Retrieved November 4, 2009 from

http://www.safetybasement.com/category_s/377.htm

American Bar Association (ABA). (2009). Section of Science and Technology Law, 301. Retrieved November 19, 2009 from

http://www.abanet.org/leadership/2008/annual/recommendations/ThreeHundre dOne.doc

International Society of Forensic Computer Examiners (ISFCE) (2009). Certified Computer Examiner. http://www.certified-computer-examiner.com/

Kramer, J. (2009). Texas Government-mandated Computer Repair License Does Not Compute, Institute for Justice. Retrieved November 19, 2009 from http://www.ij.org/index.php?option=com_content\&task=view\&id=2189\&Itemi $\mathrm{d}=129$

Lonardo, T. White, D., and Rea, A. (2008) To License or Not to License: An Examination of State Statutes Regarding

Private Investigators and Digital Examiners, The Journal of Digital Forensics, Security, and Law. 3:3

Mesis, J. (2009). Private Investigator License Requirements by State. Private Investigator Magazine. Retrieved November 4, 2009 from

http://www.pimagazine.com/links_Licensing.htm 
Rife vs. Texas Private Security Board (2007). cTex. Occ. Code $\S 1702.381$

SANS (2009). GIAC Certified Forensics Analyst. Retrieved November 19, 2009 from http://www.giac.org/certifications/security/gcfa.php

White, D., Lonardo, T. and Rea, A. (2009). pilaws. http://twitter.com/pilaws

White, D. \& Micheletti, C. (2008). Annual Survey of CCE Results. Proceedings of the Decision Sciences Institute Conference. Baltimore, MD. November. 
Journal of Digital Forensics, Security and Law, Vol. 4(3) 